\title{
Diastolic mitral regurgitation in a patient with coronary artery disease and anaemia
}

\section{Abhinav Agrawal, Manan Parikh, Isha Verma, Braghadheeswar Thyagarajan}

Department of Internal Medicine, Monmouth Medical Center, Long Branch, New Jersey, USA

\section{Correspondence to} Dr Braghadheeswar

Thyagarajan,

bragmd@gmail.com

Accepted 28 February 2016

CrossMark

To cite: Agrawal $\mathrm{A}$, Parikh M, Verma I, et al. BMJ Case Rep Published online: [please include Day Month Year] doi:10.1136/ bcr-2016-214473

\section{DESCRIPTION}

An 88-year-old man presented to the emergency department due to haematuria and blood clots in his urine. The patient's history was significant for hypertension and prostate cancer, for which he received radiotherapy. He did not have any other risk factor for coronary artery disease. On admission, his haemoglobin was $9 \mathrm{~g} / \mathrm{dL}$ (baseline $13 \mathrm{~g} / \mathrm{dL}$ ). Repeat haemoglobin on the consecutive days improved to $10 \mathrm{~g} / \mathrm{dL}$. The patient did not receive any blood transfusion during the hospital stay. $\mathrm{He}$ developed chest pain with ECG showing normal sinus rhythm at $76 \mathrm{bpm}$, new right bundle branch block and new left anterior fascicular block (bifascicular block). Troponin was elevated with peak of $7.46 \mathrm{ng} / \mathrm{dL}$ (normal $0.04-0.8 \mathrm{ng} / \mathrm{dL}$ ). Transthoracic echocardiogram showed ejection fraction of $44 \%$, presence of diastolic mitral regurgitation (DMR), and anterolateral and apical wall hypokinesia accompanied by moderate aortic regurgitation (AR). The
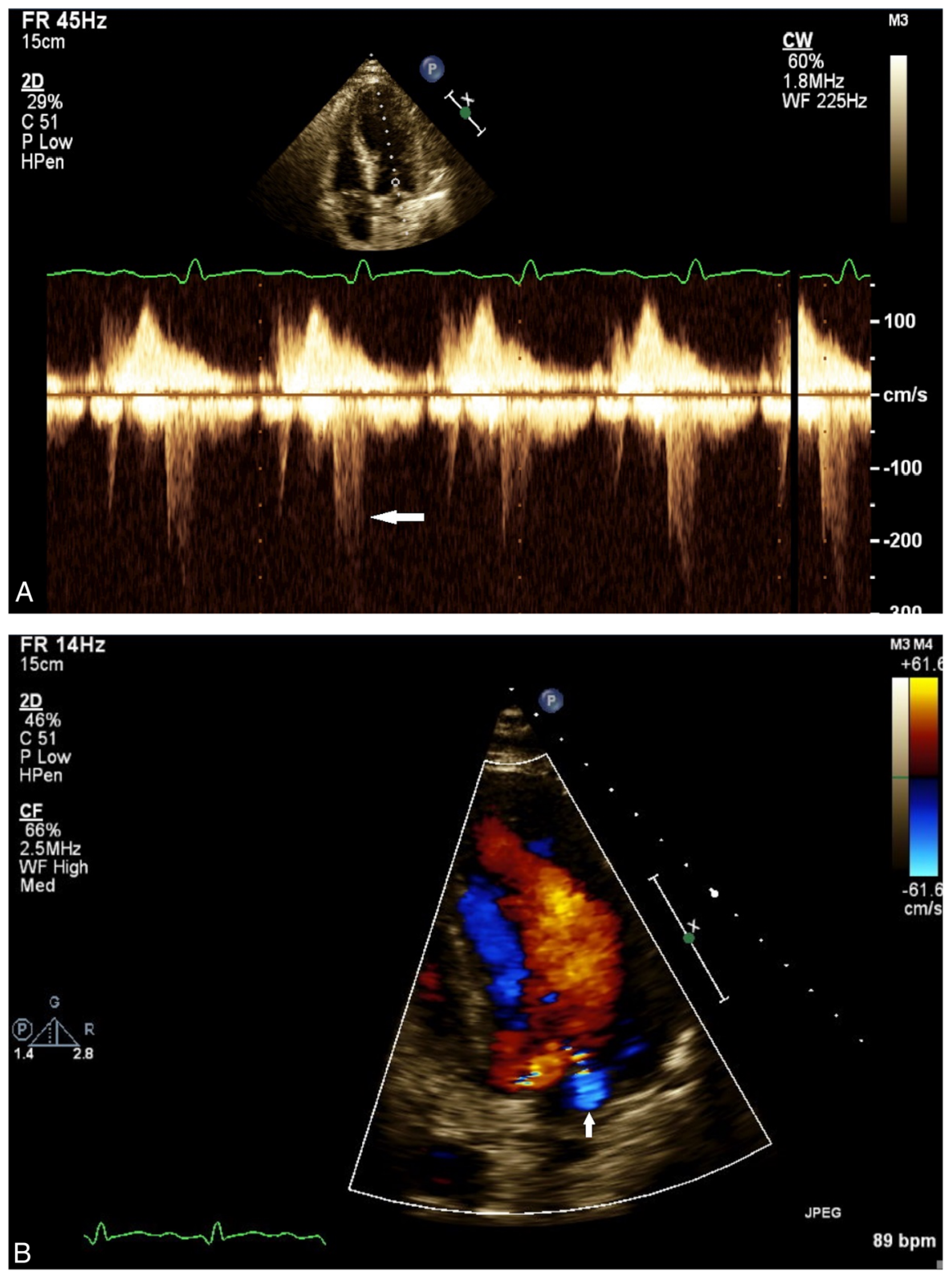

Figure 1 (A) Continuous wave Doppler image showing mid-diastolic mitral regurgitation (white arrow). (B) Colour Doppler showing diastolic mitral regurgitation (white arrow). 
Figure 2 Systolic (A) and diastolic (B) images showing apical hypokinesis (white arrow) and hyperdynamic mid-ventricular wall motion (yellow arrow) causing functional left ventricular (LV) outflow obstruction.

Figure 3 Tissue Doppler showing elevated medial $E^{\prime}$ velocity suggestive of hyperdynamic circulation.
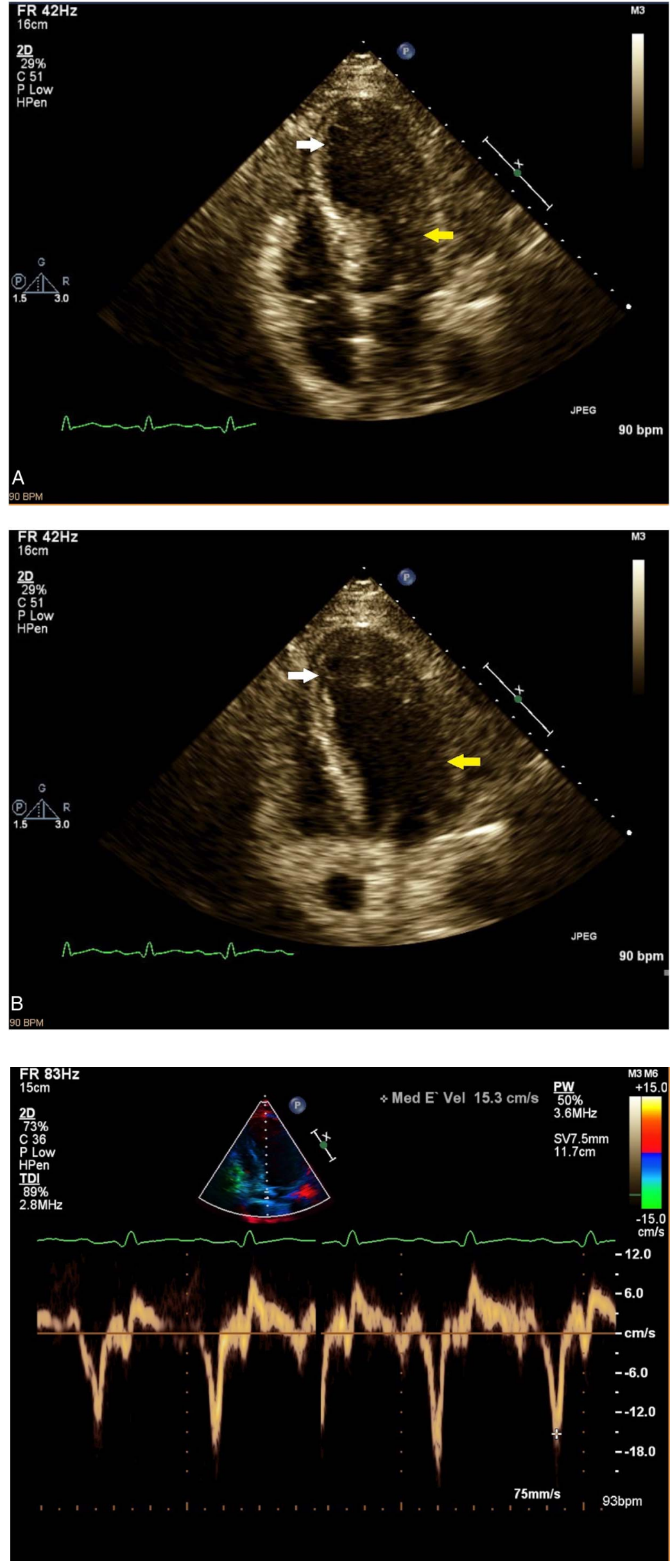
Figure 4 Colour Doppler showing aortic regurgitation.

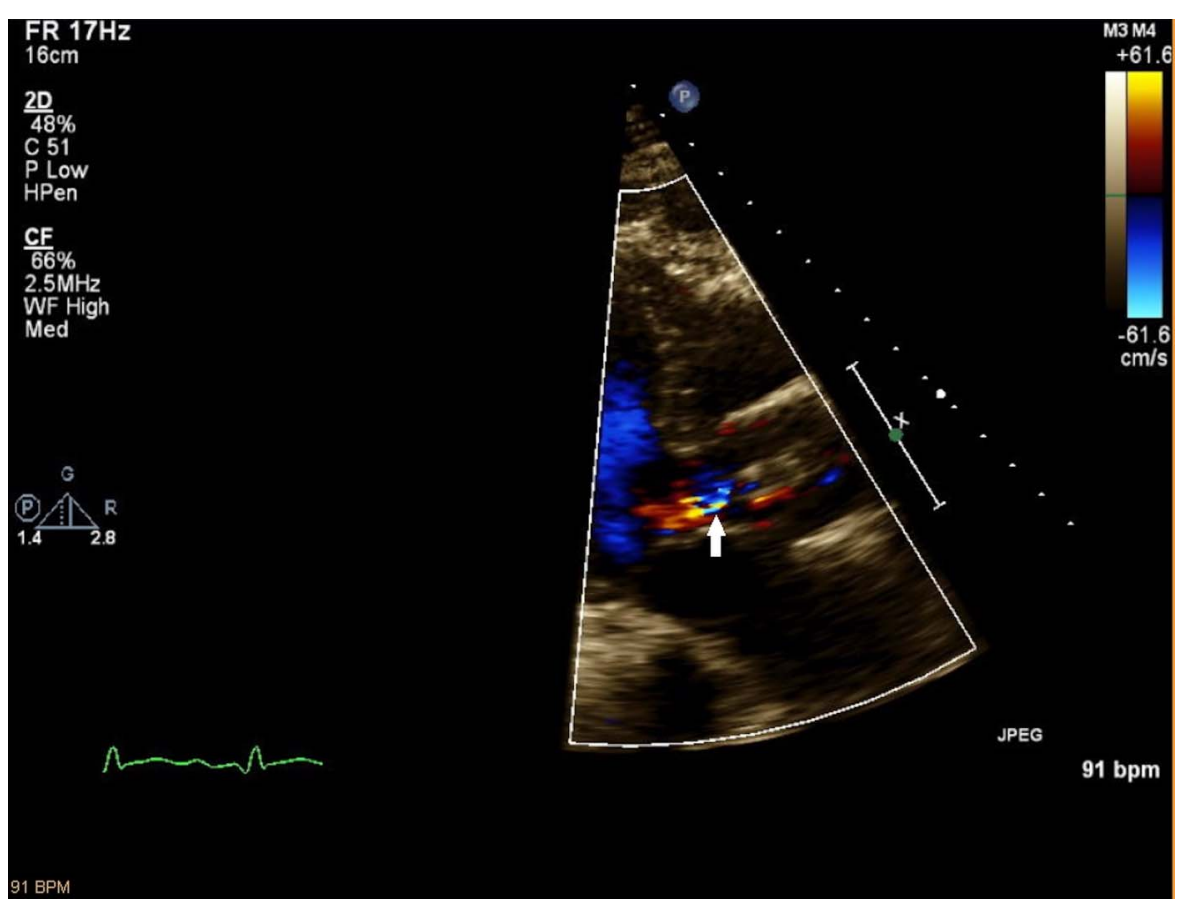

patient underwent a cardiac catheterisation, which showed fourvessel disease. He was scheduled for coronary artery bypass grafting. He was also started on iron supplements for his anaemia.

Effective left ventricular (LV) contraction is essential for the closure of the mitral valve. DMR occurs when ventricular pressure exceeds the atrial pressure during any phase of diastole, producing a reverse atrioventricular gradient. This has been

\section{Learning points}

Effective left ventricular (LV) contraction is essential for the closure of the mitral valve. Diastolic mitral regurgitation (DMR) occurs when ventricular pressure exceeds the atrial pressure during any phase of diastole, producing a reverse atrioventricular gradient.

- It can be caused by diastolic LV dysfunction, severe aortic regurgitation (AR) and atrioventricular block.

- Apical hypokinesis in the presence of hyperdynamic circulation can lead to functional LV outflow tract obstruction. This can lead to pooling of blood in LV and reversal of the atrioventricular gradient causing DMR.

- This pooling of blood can be exacerbated in the presence of moderate to severe AR leading to DMR. observed in patients with diastolic LV dysfunction, severe AR and atrioventricular blocks. ${ }^{1-3}$ In our patient, we noticed a mid-DMR on Doppler waveform (figure 1A, B). He had apical hypokinesis (figure $2 \mathrm{~A}, \mathrm{~B}$ ) in the setting of hyperdynamic circulation (figure 3 ) due to the anaemia from haematuria. This led to a functional LV outflow tract obstruction (figure 2A, B) in the absence of septal hypertrophy. This resulted in pooling of blood in the apex during systole. This was exacerbated by moderate AR (figure 4) and early diastolic filling of the LV leading to further increase in LV volume. Owing to the factors aforementioned, in diastole, there is a reversal of atrioventricular gradient across the mitral valve in diastole leading to DMR.

Twitter Follow Abhinav Agrawal at @re_innervated

Competing interests None declared.

Patient consent Obtained.

Provenance and peer review Not commissioned; externally peer reviewed.

\section{REFERENCES}

1 Agmon Y, Freeman WK, Oh JK, et al. Diastolic mitral regurgitation. Circulation 1999;99:e13.

2 Usuku H, Misumi I, Kusuhara K, et al. Mid-diastolic mitral regurgitation in a patient with diastolic heart failure. J Echocardiogr 2013;11:161-3.

3 Wong M. Diastolic mitral regurgitation haemodynamic and angiographic correlation. Br Heart J 1969;31:468-73

Copyright 2016 BMJ Publishing Group. All rights reserved. For permission to reuse any of this content visit

http://group.bmj.com/group/rights-licensing/permissions.

BMJ Case Report Fellows may re-use this article for personal use and teaching without any further permission.

Become a Fellow of BMJ Case Reports today and you can:

- Submit as many cases as you like

- Enjoy fast sympathetic peer review and rapid publication of accepted articles

- Access all the published articles

- Re-use any of the published material for personal use and teaching without further permission

For information on Institutional Fellowships contact consortiasales@bmjgroup.com

Visit casereports.bmj.com for more articles like this and to become a Fellow 